\title{
Efficacy of probiotic administration in the complex treatment of chronic catarrhal gingivitis in children
}

\author{
O. I. Godovanets, D. G. Popesku, O. S. Godovanets, V. V. Bezruk, T. O. Bezruk \\ Higher State Educational Establishment “Bukovinian State Medical University”, Chernivtsi, Ukraine
}

One of the leading pathogenic mechanisms of chronic catarrhal gingivitis development in children is disorders in the system of child macroorganism and oral cavity microorganisms interrelation as a result of normal microflora inhibition against the background of general amount of opportunistic and pathogenic microorganisms. The oral cavity protective mechanisms condition plays an important role in this process. Due to this fact a perspective direction is to study the methods of mentioned pathology treatment using probiotics containing strains of normal microflora with high antagonistic, enzymatic and immunemodeling properties able to inhibit growth of pathogenic bacteria.

Objective: to improve the common method of catarrhal gingivitis treatment in children by means of oral microbiocenosis correction on the local level.

Materials and methods. The method of catarrhal gingivitis treatment in children with administration of the probiotic "BioGaia Prodentis" has been developed. 30 children at the age of 12 with clinical signs of chronic catarrhal gingivitis were treated and dynamically observed. The children were divided into two groups: the main (with application of the improved method) and the group of comparison (the common method was applied). The periodontal tissue condition in children was assessed on the basis of OHI-S, PMA, CPI indices, and Schiller-Pisarev's test. The oral cavity local immunity was assessed by means of lysozyme activity, the level of secretory immunoglobulin $\mathrm{A}$, the degree of dysbiosis by urease activity detection in the oral fluid of children.

Results. Administration of the drug "BioGaia Prodentis" in the complex of chronic catarrhal gingivitis treatment in children resulted in a quick reverse development of clinical signs. Among the children of the main group on the $3-4^{\text {th }}$ day of treatment a tendency to subsidence of inflammatory signs was observed. In the group of comparison the signs such as hyperemia, swelling and bleeding regressed at the beginning of the $4-5^{\text {th }}$ day. An average duration of local treatment in the main group was $4.46 \pm 0.27$ days against $8.00 \pm 0.36$ days in the group of comparison $(P<0.05)$. The results of paraclinical examination of children oral cavity after treatment have become the evidence of the clinical changes found. Significant difference by all the indices in children of the main group was detected. Catamnestic examination demonstrated that in half a year in children who were treated with the medicine "BioGaia Prodentis" better clinical-paraclinical indices were registered twice as less than those in children from the comparison group.

Conclusions. Treatment of chronic catarrhal gingivitis in children with administration of the medicine "BioGaia Prodentis" in a complex therapy contributes to oral cavity microbiocenosis normalization. Clinical efficacy of the proposed method is evidenced by the local treatment periods reduction almost twice as large and approximately $2 / 3$ decreased of the disease signs relapse as compared to the initial indices.

\section{Ефективність застосування пробіотика в комплексі Аікування хронічного катарального гінгівіту в дітей}

\section{О. І. Годованець, А. Г. Попеску, О. С. Годованець, В. В. Безрук, Т. О. Безрук}

Одним із провідних патогенетичних механізмів розвитку хронічного катарального гінгівіту в дітей $є$ порушення в системі взаємодії макроорганізму дитини та мікроорганізмів ротової порожнини як наслідок пригнічення нормальної мікрофрлори на тлі зростання загальної маси представників умовно-патогенних і патогенних мікроорганізмів. Вагоме значення при цьому відіграє стан захисних механізмів ротової порожнини. У зв'язку з цим перспективним є дослідження методів лікування цієї патології з використанням пробіотиків, до складу яких входять штами представників нормальної мікрофлори, з високими антагоністичними, ферментативними й імуномодулюючими властивостями, що здатні пригнічувати ріст патогенних бактерій.

Мета роботи - удосконалення загальноприйнятого методу лікування хронічного катарального гінгівіту в дітей шляхом корекції мікробіоценозу ротової порожнини на місцевому рівні.

Матеріали та методи. Розроблено метод лікування хронічного катарального гінгівіту в дітей із застосуванням пробіотика «BioGaia Prodentis». Провели лікування та динамічне спостереження протягом 6 місяців за 30 дітьми віком 12 років із клінічними ознаками хронічного катарального гінгівіту. Дітей поділили на дві групи: основну (застосовано удосконалений метод) і порівняння (застосовано загальноприйнятий метод). Стан тканин пародонта в дітей оцінили на основі індексів OHI-S, PMA, CPI та проби Шиллера-Писарєва. Місцевий імунітет ротової порожнини оцінювали шляхом визначення активність лізоциму, рівня секреторного імуноглобуліну А, а також ступеня дисбіозу за активністю уреази в ротовій рідині дітей.

Результати. Застосування препарату «BioGaia Prodentis» у комплексі лікування хронічного катарального гінгівіту в дітей призвело до швидкого зворотного розвитку клінічної симптоматики. У дітей основної групи вже на 3-4 добу лікування спостерігали тенденцію до зникнення ознак запалення. У групі порівняння явища гіперемії, набряку та кровоточивості піддавалися регресії, починаючи з 4-5 доби. Середня тривалість місцевого лікування в основній групі становила 4,46 \pm 0,27 дня проти 8,00 $\pm 0,36$ дня у групі порівняння $(p<0,05)$. Підтвердженням встановлених клінічних 
змін стали результати параклінічного дослідження ротової рідини дітей після лікування. Виявлена вірогідна різниця за всіма показниками в дітей основної групи. Катамнестичне спостереження показало: через півроку в дітей, яким проводили лікування з препаратом «BioGaia Prodentis», реєстрували майже вдвічі кращі клініко-параклінічні показники, аніж у дітей групи порівняння.

Висновки. Лікування хронічного катарального гінгівіту в дітей із застосуванням у комплексі терапії препарату «BioGaia Prodentis» сприяє нормалізації мікробіоценозу ротової порожнини. Клінічна ефективність запропонованого методу підтверджується скороченням термінів місцевого лікування майже вдвічі та зменшенням рецидивування ознак захворювання приблизно на 2/3 порівняно з вихідними показниками.

Ключевые слова: гингивит, пробиотики, Аети.

Запорожский медицинский журнал. - 2018. -

T. 20, № 2(107). C. 211-215

\section{Эффективность применения пробиотика в комплексе лечения хронического катарального гингивита у детей}

\section{О. И. Годованец, А. Г. Попеску, А. С. Годованец, В. В. Безрук, Т. А. Безрук}

Одним из ведущих патогенетических механизмов развития хронического катарального гингивита у детей являются нарушения в системе взаимодействия макроорганизма ребенка и микроорганизмов ротовой полости как следствие подавления нормальной микрофлоры на фоне роста общей массы представителей условно-патогенных и патогенных микроорганизмов. Большое значение при этом играет состояние защитных механизмов ротовой полости. В связи с этим перспективным направлением является исследование методов лечения данной патологии с использованием пробиотиков, в состав которых входят штаммы представителей нормальной микрофрлоры, с высокими антагонистическими, ферментативными и иммуномодулирующими свойствами, способными подавлять рост патогенных бактерий.

Цель работы - совершенствование общепринятого метода лечения хронического катарального гингивита у детей путем проведения коррекции микробиоценоза ротовой полости на местном уровне.

Материалы и методы. Разработан метод лечения хронического катарального гингивита у детей с применением пробиотика «BioGaia Prodentis». Проведено лечение и динамическое наблюдение в течение 6 месяцев за 30 детьми в возрасте 12 лет с клиническими признаками хронического катарального гингивита. Дети были разделены на две группы: основную (применен усовершенствованный метод) и сравнения (применен общепринятый метод). Состояние тканей пародонта у детей оценили на основе индексов OHI-S, PMA, СРИ и пробы Шиллера-Писарева. Местный иммунитет полости рта оценивали путем определения активности лизоцима, уровня секреторного иммуноглобулина А, а также степени дисбиоза по активности уреазы в ротовой жидкости детей.

Результаты. Применение препарата «BioGaia Prodentis» в комплексе лечения хронического катарального гингивита у детей привело к быстрому обратному развитию клинической симптоматики. У детей основной группы уже на 3-4 сутки лечения отмечена тенденция к исчезновению признаков воспаления. В группе сравнения явления гиперемии, отека и кровоточивости подвергались регрессии, начиная с 4-5 суток. Средняя продолжительность местного лечения в основной группе составила 4,46 $\pm 0,27$ дня против 8,00 $\pm 0,36$ дня в группе сравнения $(p<0,05)$. Подтверждением установленных клинических изменений стали результаты параклинического исследования ротовой жидкости детей после лечения. Обнаружена достоверная разница по всем показателям у детей основной группы. Катамнестическое наблюдение показало, что через полгода у детей, которым проводили лечение с препаратом «BioGaia Prodentis», регистрировали почти в 2 раза лучшие клинико-параклинические показатели, чем у детей группы сравнения.

Выводы. Лечение хронического катарального гингивита у детей с применением в комплексе терапии препарата «BioGaia Prodentis» способствует нормализации микробиоценоза ротовой полости. Клиническая эффеективность предложенного метода подтверждается сокращением сроков местного лечения почти вдвое и уменьшением рецидивирования признаков заболевания примерно на 2/3 по сравнению с исходными показателями.

\section{Introduction}

In children at the age of 12-15 years chronic catarrhal gingivitis (CCG) is registered in $70-80 \%$ of cases reaching $95-98 \%$ in certain regions $[1,3]$. One of the leading pathogenic mechanisms of chronic catarrhal gingivitis development in children is disorders in the system of child macroorganism and oral cavity microorganisms interrelation as a result of normal microflora inhibition against the background of opportunistic and pathogenic microorganisms general amount. The oral cavity protective mechanisms condition plays an important role in this process. In addition, antibiotic or antiseptics in the complex of CCG treatment are usually used that can cause dysbacteriosis.

In this respect a perspective direction is to study the methods of mentioned pathology treatment using probiotics $[4,6-8]$. Among a wide range of probiotics our attention was drawn to the probiotic "BioGaia Prodentis" specifically developed for local effect in the oral cavity. It contains about 100 million bacteria of Lactobacillus reuteri DSM 17938 (per one lozenge), approximately 100 million bacteria of Lactobacillus reuteri 5289 (per one lozenge) and additives: isomalt DC 100 (E 953); hydrogenated palm oil, sucrose esters of fatty acids, mint flavor, menthol flavor, mint oil, sucralose (E 955). The mechanism of "BioGaia Prodentis" action is unique as it secretes natural inhibitors of wide spectrum pathogenic microorganisms growth including the antimicrobial compound reuterin which is specific only to the microorganisms Lactobacillus reuteri [5].

\section{Objective}

To improve the common method of catarrhal gingivitis treatment in children by means of oral microbiocoenosis correction on the local level. 


\section{Materials and methods}

The method of catarrhal gingivitis treatment in children with administration of the probiotic "BioGaia Prodentis" has been developed. 30 children at the age of 12 years with clinical signs of chronic catarrhal gingivitis were treated and dynamically observed. The children were divided into two groups: I - the main (with application of the improved method) and II - the group of comparison (the common method applied). The following risk factors of gingivitis for this age group of children, included into the groups of observation and comparison, as somatic, orthodontic pathology, high intensity of dental caries, were absent. Therefore, a cause of the disease was generally accepted hygienic factor.

The common method of CCG treatment included sanitation and professional oral hygiene, antiseptic (oral rinsing with $0.05 \%$ chlorhexidine gluconate solution) and anti-inflammatory (applications with "Rotocan") therapy. In addition to the common measures the children of the main group received the correction of the oral microbiocoenosis using the probiotic "BioGaia Prodentis" 1 tablet twice a day after cleaning the teeth during 14 days.

To assess the condition of the oral hygiene the simplified hygiene Green-Vermillion (OHI-S) index was applied. The condition of the periodontal tissue in children was assessed on the basis of OHI-S, PMA, CPI indices and Schiller-Pisarev's test.

The local oral cavity immunity was assessed by means of detection of secretory immunoglobulin $\mathrm{A}$ (slgA) content using radial immunodiffuse method according to Manchini G., and lysozyme activity using A. P. Levytsky's method [2]. The degree of oral dysbiosis was examined through the enzymatic method by urease activity [2]. The method is based on the ability of urease to decompose urea with ammonia formation which amount is detected by means of Nessler reagent.

Statistical analysis was performed using the biostatistics methods of the licensed program Statistica 6.0 (StatSoft, USA). The mean value $(M)$, mean error $(m)$, reliability of statistical indices $(p)$ have been taken for consideration. The data have been presented in the form of $(\mathrm{M} \pm \mathrm{m})$ and were considered reliable by the level of statistical significance of $P<0.05$.

\section{Results}

Complaints of children from the observation groups analysis did not find any difference between them. Thus, in the I group 7 children (46.67\%) complained about bleeding, 4 children $(26.67 \%)$ - pain in the gums, 1 child $(6.67 \%)$ itching and 2 children (13.33 \%) - unpleasant smell from the mouth. Similar complaints were admitted by the children of the II group: bleeding - 7 individuals (46.67\%), painful sensations -3 persons $(20.00 \%)$, itchiness in the gums 2 children (13.33\%). The structure of complaints among the children from the groups of observation was similar.

According to the sex and physical development of children the groups of observation were compatible. Thus, in the I group there were 8 boys $(53.33 \%)$ and in the II group -7 boys ( $46.67 \%)$.

Assessment of general somatic condition of children demonstrated an equal level of the examined children health from the I and II groups: per 10 persons $(66.67 \%)$ with the I group of health and per 5 children $(33.33 \%)$ with the II group.

The clinical assessment of the periodontal tissue condition of children from the observation groups before the beginning of treatment by the data of indices and tests is presented in the Table 1 and it is indicative of the significant difference absent between the indices of the I and II groups. Analysis of paraclinical indices, and slgA level in particular, lysozyme and urease activity enables to conclude the uniformity of protective mechanisms changes in the oral cavity in children from the groups of observation (Table 2).

Administration of the drug "BioGaia Prodentis" in the chronic catarrhal gingivitis complex treatment in children resulted in a quick clinical signs regression. Among the children of the main group on the $3-4^{\text {th }}$ day of treatment a tendency to subsidence of inflammatory signs was observed. In the group of comparison the signs such as hyperemia, swelling and bleeding regressed at beginning of the $4-5^{\text {th }}$ day. An average duration of local treatment in the main group was $4.46 \pm 0.27$ days against $8.00 \pm 0.36$ days in the group of comparison $(P<0.05)$.

The clinical examination of children after the course of initiated treatment (the $14^{\text {th }}$ day) detected a complete elimination of pathological process in the gums after administration of "BioGaia Prodentis". Contrary to these findings in the group of comparison the signs of inflammation were observed in 5 children (33.33\%). The condition of the periodontal tissue by the indices of PMA, bleeding and Schiller-Pisaref test in the dynamics of treatment is presented in Table 1.

Oral hygiene in the groups of observation on the moment of treatment completion was assessed as "good". Analysis of periodontal criteria in the main group demon-

Table 1. Index assessment of the periodontal tissue condition in children of the observation group, $\mathrm{M} \pm \mathrm{m}$

\begin{tabular}{|c|c|c|c|c|c|}
\hline Indices, units of measurement & Groups of children & $\begin{array}{l}\text { Before treatment } \\
(n=15)\end{array}$ & $\begin{array}{l}\text { After treatment } \\
(n=15)\end{array}$ & $\begin{array}{l}1 \text { month later } \\
(n=14)\end{array}$ & $\begin{array}{l}6 \text { months later } \\
(n=13)\end{array}$ \\
\hline \multirow[t]{2}{*}{ Hygienic index, OHI-S } & main & $1.19 \pm 0.09$ & $0.37 \pm 0.05^{\bullet}$ & $0.44 \pm 0.04$ & $0.72 \pm 0.07^{\#}$ \\
\hline & comparison & $1.21 \pm 0.10$ & $0.37 \pm 0.06 \bullet$ & $0.54 \pm 0.06$ & $0.79 \pm 0.09 \#$ \\
\hline \multirow[t]{2}{*}{ PMA index, \% } & main & $25.56 \pm 1.46$ & $0 \cdot$ & $1.41 \pm 0.57^{\wedge}$ & $7.38 \pm 0.82 \#$ \\
\hline & comparison & $23.44 \pm 1.05$ & $3.96 \pm 1.05$ *• & $7.02 \pm 0.85$ * & $12.07 \pm 1.34$ *\#\# \\
\hline \multirow[t]{2}{*}{ Schiller-Pisaref test, score } & main & $1.50 \pm 0.07$ & 0 & $0.10 \pm 0.03^{\wedge}$ & $0.33 \pm 0.03^{\#}$ \\
\hline & comparison & $1.53 \pm 0.05$ & $0.16 \pm 0.04 * \bullet$ & $0.38 \pm 0.05^{*, \Lambda}$ & $0.60 \pm 0.07^{\text {*\#\# }}$ \\
\hline \multirow[t]{2}{*}{ Bleeding, sextants } & main & $3.80 \pm 0.07$ & $0 \cdot$ & $0.17 \pm 0.03^{\wedge}$ & $1.33 \pm 0.08 \#$ \\
\hline & comparison & $3.69 \pm 0.08$ & $0.16 \pm 0.04^{* \bullet}$ & $0.38 \pm 0.05^{*, \Lambda}$ & $1.54 \pm 0.07^{*, \#}$ \\
\hline
\end{tabular}

*: significant difference of indices in the main group and the comparison group, $P<0.05 ; \cdot$ : significant difference of indices in the groups before and after treatment, $P<0.05$;

$\wedge$ : significant difference of indices in the groups after treatment and 1 month later, $P<0.05$; : significant difference of indices in the groups within 1 and 6 months after treatment, $P<0.05$. 
Table 2. Condition of oral cavity protective mechanisms in children from the groups of observation, $M \pm m$

\begin{tabular}{llll}
\hline Indices, units of measurement & Main Group & Comparison Group \\
\cline { 2 - 4 } & $\begin{array}{l}\text { Before treatment } \\
(\mathbf{n}=15)\end{array}$ & $\begin{array}{l}\text { After treatment } \\
(\mathbf{n}=15)\end{array}$ & $\begin{array}{l}\text { Before treatment } \\
(\mathbf{n}=15)\end{array}$ \\
\hline Lysozyme, units/L & $23.45 \pm 1.43^{*}$ & $34.08 \pm 2.17^{\wedge}$ & $25.01 \pm 1.25^{*}$ \\
Urease, mcmol/(min-L) & $32.19 \pm 2.72^{*}$ & $23.15 \pm 1.23^{\wedge}$ & $31.05 \pm 1.11^{*}$ \\
slgA, g/L & $0.35 \pm 0.02^{*}$ & $0.32 \pm 0.01^{\wedge}$ & $0.36 \pm 0.02^{*}$ \\
\hline
\end{tabular}

*: significant difference of indices in the main group and the comparison group, $P<0.05 ; \cdot$ significant difference of indices in the I and II groups after treatment, $P<0.05$;

$\because$ : significant difference of indices in the I and II groups before treatment, $\mathrm{P}<0.05$; $^{\wedge}-$ significant difference of indices before and after treatment in the I group, $\mathrm{P}<0.05$;

\#: significant difference of indices before and after treatment in the II group, $P<0.05$.

strated the absence of their difference in comparison with the indices of healthy children which is indicative of periodontal tissues structure and functions complete restoration. At the same time, in children from the group of comparison in spite of their complaints absence on the moment of treatment completion PMA index was $(3.96 \pm 1.05) \%$, and the number of sextants with bleeding $-(0.16 \pm 0.04)$, which is indicative of less efficacy of the common method of CCG treatment in children.

The observed clinical changes have become evidenced by the results of paraclinical examinations of the oral fluid in children after treatment (Table 2). The significant difference has been found between all the indices of the main group before and after treatment. The oral cavity protective mechanisms condition in children from the I group at the end of treatment was identical to that of the control, while in children of the II group it was characterized by much worse findings, significantly different from that of the control. The indices in the comparison group after correction had a positive dynamics of examined parameters changes, although they differed from those of the main group $(P<0.05)$. The data obtained are indicative of oral cavity protective systems normal functioning incomplete restoration in case of the common method of treatment and benefits of the developed method of a complex therapy.

Clinical examinations of children carried out 1 month after treatment showed the following results. Condition of the oral hygiene remained "good" in both groups. In the group of comparison 4 children admitted relapsing bleeding gums ( $26.67 \%$ ), CCG signs were found in $66.67 \%$ of the examined individuals and included the signs of bleeding. In children of the I group relapses of the disease in the form of initial inflammatory phenomena without the signs of bleeding were found in 4 individuals $(26.67 \%)$, and in 3 children punctate bleeding was observed $(20.00 \%)$.

Catamnestic examination of children half a year later after treatment found a considerable percentage of CCG relapses in the groups of observation. 2 children (13.33\%) in the I group complained of bleeding, more complaints were found in the group of comparison: 5 persons $(33.33 \%)$. Degree of periodontal tissues damage was also different: in children who received treatment with "BioGaia Prodentis" the examined indices and tests were registered twice as much better than in children from the group of comparison. OHI-S index in both groups 6 months later after treatment deteriorated, although it was significantly lower of those indices before treatment $(P<0.05)$. Analysis of the main periodontal indices (PMA index, Schiller-Pisaref test, bleeding) in the main group was indicative of one third increase of the disease relapse as compared to the initial level, which necessitates repeated conduction of the suggested therapeutic-preventive complex initiation.

\section{Conclusions}

1. Treatment of CCG in children with administration of "BioGaia Prodentis" in a complex therapy promotes the oral cavity microbiocoenosis normalization.

2. Clinical efficacy of the suggested method is evidenced by twice as much reduction of the local treatment terms and approximately $2 / 3$ decreased of disease signs relapse as compared to the initial indices.

The prospects of further studies are administration of probiotics for the prevention of periodontal tissue diseases in children.

\section{References}

[1] Jantszarek, M., Bachanek, T., Mazur, E., \& Chałas, R. (2016). The role of probiotitss in prevention of oral diseases. Postepy Hig Med Dosw., 4, 70(0), 850-7. doi: 10.5604/17322693.1214381.

[2] Levickij, A. P., Makarenko, O. A., \& Selivanskaya, I. A. (2007) Fermentativnyij metod opredeleniya disbioza polosti rta dlya skrininga pro- $i$ prebiotikov [Enzymatic method for determining oral dysbiosis for screening pro- and prebiotics]. Kyiv. [in Russian].

[3] Marchenko, O. A. (2015) Kliniko-mikrobiolohichne obgruntuvannia dyferentsiiovanykh pidkhodiv do likuvannia khronichnoho heneralizovanoho kataralnoho hinhivitu u ditei shkilnoho viku (Dis...kand. med. nauk). [Clinical and microbiological substantiation of differentiated approaches to the treatment of chronic generalized catarrhal gingivitis in school-age children. Dr. med. sci. diss.]. Kyiv. [in Ukrainian].

[4] Polischuk, T. V. (2013) Klinichna efektyvnist kompleksu pre- ta probiotyku u likuvanni khronichnoho heneralizovanoho kataralnoho hinhivitu u ditei [Microbiological effectiveness of prebiotic-probiotic complex in the therapy of generalized catarrhal]. VISNYK VDNZU "Ukrainska medychna stomatolohichna akademiia», 13(2), 52-55. [in Ukrainian].

[5] Savchuk, N. (2013) Innovatsiini pidkhody do profilaktyky kariiesu zubiv u ditei i vahitnykh zhinok [Innovative approaches to the dental caries prevention in children and pregnant women]. Sovremennaya stomatologiya, 5, 46-50. [in Ukrainian].

[6] Cagetti, M. G., Mastroberardino, S., Milia, E., Cocco, F., Lingström, P., \& Campus, G. (2013) The use of probiotic strains in caries prevention: a systematic review. Nutrients, 5(7), 2530-50. doi: 10.3390/nu5072530.

[7] Fernández, C.E., Giacaman, R. A., Tenuta, L. M., \& Cury, J. A. (2015) Effect of the Probiotic Lactobacillus rhamnosus LB21 on the Cariogenicity of Streptococcus mutans UA159 in a Dual-Species Biofilm Model. Caries Res., 49(6), 583-90. doi: 10.1159/000439315.

[8] Ashwin, D., Ke, V., Taranath, M., Ramagoni, N. K., Nara, A., \& Sarpangala, M. (2015) Effect of Probiotic Containing Ice-cream on Salivary Mutans Streptococci Levels in Children of 6-12 Years of Age: A Randomized Controlled Double Blind Study with Six-months Follow Up. J Clin Diagn Res., 9(2), ZC06-9. doi: 10.7860/JCDR/2015/ 10942.5532 .

\section{Information about authors:}

Godovanets O. I., MD, PhD, DSc, Associate Professor, Department of Surgical and Pediatric Stomatology, Higher State Educational Establishment "Bukovinian State Medical University", Chernivtsi, Ukraine.

Popescu D. G., MD, Master of Medicine, Department of Surgical and Pediatric Stomatology, Higher State Educational Establishment "Bukovinian State Medical University", Chernivtsi, Ukraine. 
Godovanets 0. S., MD, PhD, Assistant, Department of Pediatrics, Neonatology and Perinatology of Medicine, Higher State

Educational Establishment "Bukovinian State Medical University”, Chernivtsi, Ukraine.

ResearcherID: B-1224-2017.

Bezruk V. V., MD, PhD, Associate Professor, Department of Pediatrics, Neonatology and Perinatology of Medicine, Higher State Educational Establishment “Bukovinian State Medical University", Chernivtsi, Ukraine.

Researcher ID: B-8621-2017.

Bezruk T. O., MD, PhD, Associate Professor, Department of Internal Medicine and Infectious Diseases, Higher State Educational Establishment "Bukovinian State Medical University", Chernivtsi, Ukraine.

Researcher ID: c-9965-2017.

\section{Відомості про авторів:}

Годованець О. І., А-р меА. наук, Аоцент каф. хірургічної та Аитячої стоматології, ВАНЗ "Буковинський Аержавний медичний університет", м. Чернівці, Україна.

Попеску А. Г., магістр каф. хірургічної та Аитячої стоматології, ВАНЗ “Буковинський Аержавний медичний університет", м. Чернівці, Україна.

Годованець О. С., канА. меА. наук, асистент каф. педіатрії, неонатології та перинатальної меАицини, ВАНЗ "Буковинський Аержавний медичний університет", м. Чернівці, Україна. Безрук В. В., канА. меА. наук, доцент каф. педіатрії, неонатології та перинатальної меАицини, ВАНЗ «Буковинський державний меАичний університет", м. Чернівці, Україна.

Безрук Т. О., канд. меА. наук, Аоцент каф. внутрішньої медицини та інфекційних хвороб, ВАНЗ «Буковинський Аержавний медичний університет", м. Чернівці, Україна.

\section{Сведения об авторах:}

Годованец О. И., А-р меА. наук, Аоцент каф. хирургической и Аетской стоматологии, ВГУЗ “Буковинский государственный меАицинский университет", г. Черновцы, Украина. Попеску А. Г., магистр каф. хирургической и Аетской стоматологии, ВГУЗ “Буковинский государственный медицинский университет", г. Черновцы, Украина. Годованец А. С., канА. меА. наук, ассистент каф. педиатрии, неонатологии и перинатальной меАицины, ВГУЗ “Буковинский государственный медицинский университет", г. Черновцы, украина.

Безрук В. В., канА. меА. наук, Аоцент каф. пеАиатрии, неонатологии и перинатальной медицины, ВГУЗ "Буковинский государственный медицинский университет", г. Черновцы, Украина.

Безрук Т. А., канА. меА. наук, Аоцент каф. внутренней медицины и инфекционных болезней, ВГУЗ “Буковинский государственный медицинский университет", г. Черновцы, украина.

Conflicts of Interest: authors have no conflict of interest to declare. Конфлікт інтересів: віАсутній.

Надійшла Ао редакції / Received: 11.07.2017

Після Аоопрацювання / Revised: 18.07.2017

Прийнято АО Аруку / Accepted: 31.07.2017 